
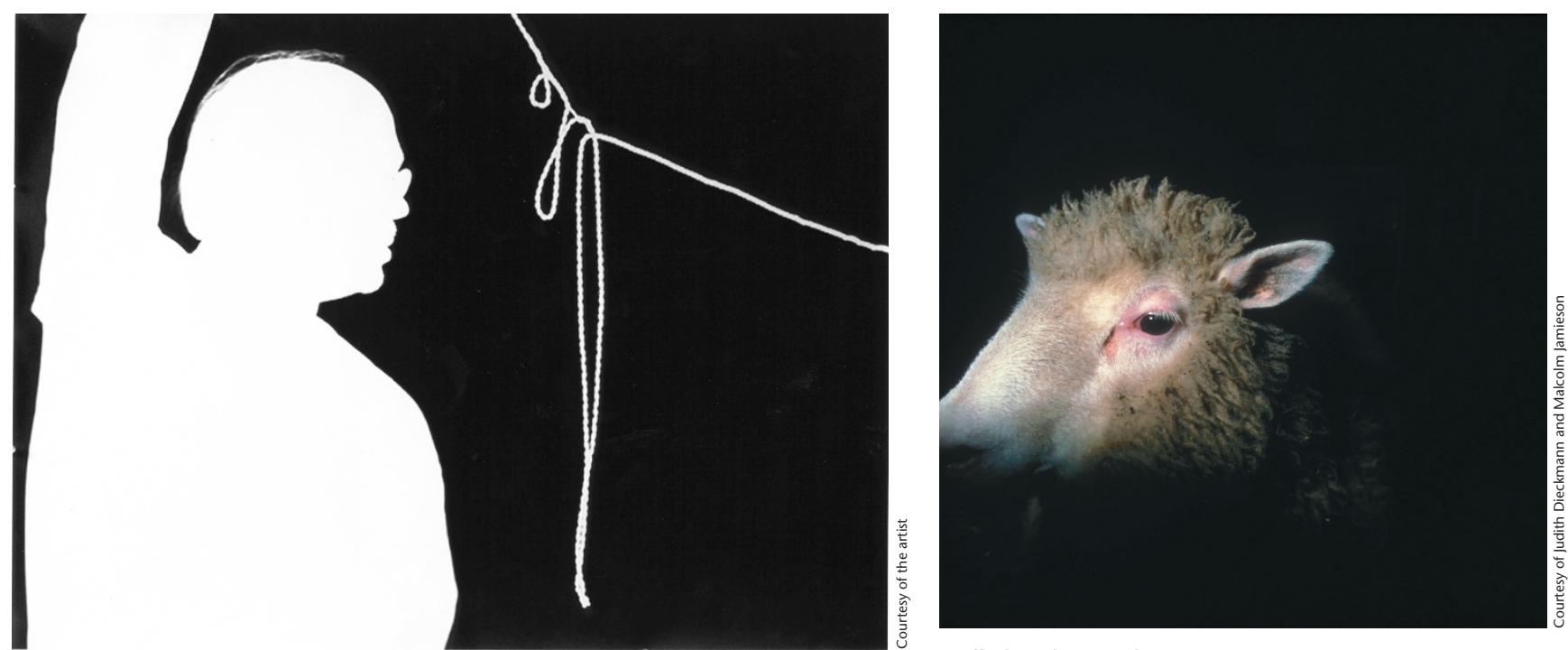

Dr. Phillip A. Sharp by Kunié Sugiura, 2003

\title{
Art imitates life
}

The 1953 discovery of DNA's double helix was more than a scientific breakthrough-its elegant beauty has become engrained in our culture, inspiring scientists and artists alike. Around the world this year, the fiftieth anniversary of Watson and Crick's famous discovery is being celebrated in creative and unusual ways.

Several galleries and museums are honoring the anniversary with DNAthemed exhibits, including How Human: Life in the Post-Genome Era at the International Center of Photography in New York and Representations of the Double Helix at Cambridge University's Whipple Museum. The UK Royal Mail recognized genomic research through a series of five special stamps, including one depicting a cartoon double helix. Even designers have been inspired by the molecule: Andrea Valentini's DNA necklace uses intertwined strings of beads to represent the complex molecule, and a striking design by Helen and Kate Storey features a woman wearing a helical red dress of DNA sequencing gel. Not surprisingly, the ones most excited about the anniversary are scientists themselves: an autographed print of James Watson and Francis Crick posing with their DNA model, released for the anniversary by Science Photo Gallery and auctioned at the International Congress of Genetics, was worth $\$ 3,850$ as Nature Medicine went to press.

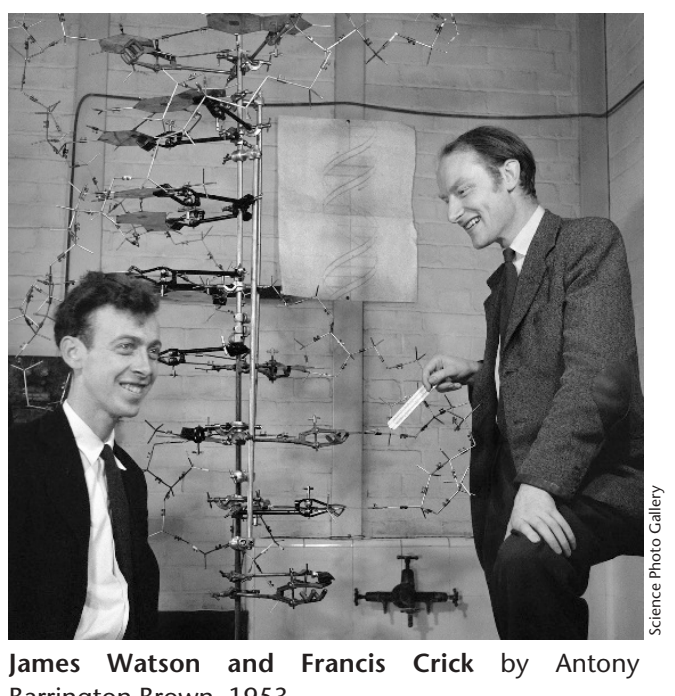

Barrington Brown, 1953

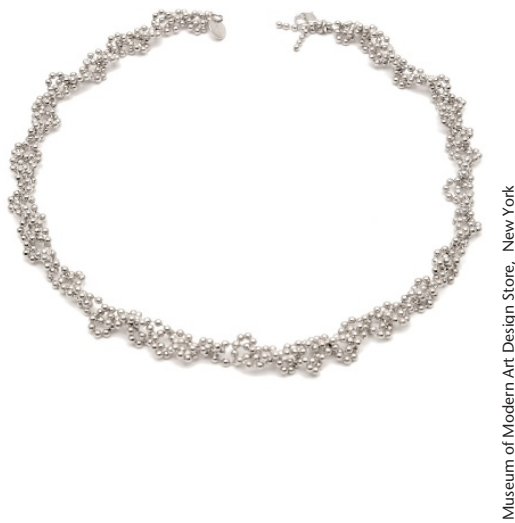

DNA Necklace by Andrea Valentini, 2002
Dolly by Chris Buck, 1997

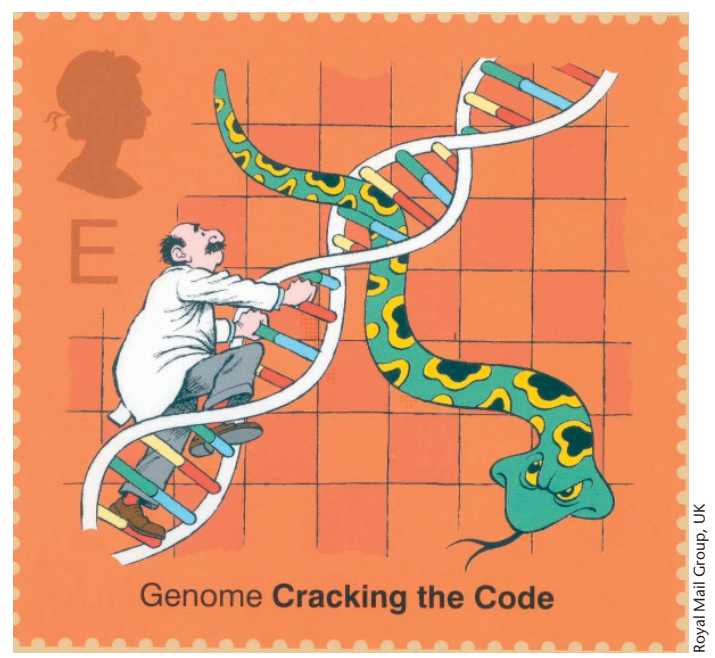

Cracking the Code by Williams Murray Hamm (design) and Peter Brookes (illustration), 2003 